\title{
TATA KRAMA DALAM ADAT ISTIADAT ORANG KATOBENGKE DI KOTA BAU-BAU PROUINSI SULAWESI TENGgaRA
}

\section{MANNERS IN THE CUSTOMS OF THE KATOBENGKE PEOPLE IN BAU-BAU CITY PROVINCE OF SOUTHEAST SULAWESI}

\author{
Raodah \\ Balai Pelestarian Nilai Budaya Makassar \\ Jalan Sultan Alauddin Km7 Makassar, 90221 \\ e-mail: raodahtul.janna@yahoo.com
}

DOI: 10.30959/patanjala.v11i2.475

\begin{abstract}
Abstrak
Tata krama dalam adat istiadat orang Katobengke mencerminkan perilaku mereka dalam kehidupan sehari-hari dalam berinteraksi. Tulisan ini bertujuan untuk mengetahui dan mendeskripsikan bentuk-bentuk tata krama orang Katobengke dalam lingkup keluarga dan masyarakat, serta tata krama dalam berbagai upacara adat. Metode yang digunakan dalam penelitian ini bersifat deskriptif dengan pendekatan kualitatif. Teknik pengumpulan data melalui observasi dengan penentuan lokasi secara purposive, wawancara mendalam dengan informan yang dipilih secara acak dari tokoh adat, parabela, imam kampung, dan warga Katobengke, serta teknik dokumentasi. Hasil penelitian menggambarkan bahwa tata krama orang Katobengke sangat dipengaruhi oleh norma adat yang berlaku, dan sesuai tuntunan parabela selaku ketua adat. Bentuk-bentuk tata krama dalam pergaulan dan kehidupan sehari-hari meliputi tata krama dalam menyapa dan bersikap, tata krama duduk, makan dan minum, berpakaian serta berinteraksi dengan masyarakat. Sedang tata krama dalam upacara adat (haruo) meliputi: Tuturangi Lipu Morikana, Posuo, upacara perkawinan, dan beberapa ritual adat yang masih berpegang teguh sesuai ajaran leluhur orang Katobengke.
\end{abstract}

Kata kunci: orang Katobengke, tata krama, parabela

\begin{abstract}
Manners in the customs of the Katobengke people reflect their behavior in daily life. This paper aims to find out and describe the form of Katobengke manners within family and community, as well as manners in various traditional ceremonies. The method used in this study is descriptive with a qualitative approach. Data collection techniques are carried out through field observation by determining the location in a purposive manner, depth interviews with informans randomly selected from traditional leaders, parabela, village priests, and residents of Katobengke, as well as documentation techniques. The results of the study illustrate that manners of Katobengke people are strongly influenced by the custumory norms that apply and in accordance with parabela guidance as customary leader. The forms of manners in society and daily life include manners in greeting and behaving, manners of sitting, dressing, eating and drinking, as well as interacting with community; while manners in traditional ceremonies include Tuturangi Lipu Morikana, Posuo, marriage ceremonies, and some traditional rituals, which still adhere to the ancestors teaching of Katobengke people.
\end{abstract}

Keywords: Katobengke people, manners, parabola.

\section{A. PENDAHULUAN}

Tata krama adalah kebiasaan sopan santun yang disepakati dalam lingkungan pergaulan antar manusia setempat. Tata krama merupakan tata cara atau aturan turun- temurun yang berkembang dalam suatu budaya masyarakat yang mengatur pergaulan antar individu maupun 
kelompok untuk saling pengertian, hormatmenghormati menurut adat yang berlaku pada daerah setempat. Di dalam berbagai unsur misalnya kebiasaan, adat istiadat dan norma-norma yang berlaku turut menentukan perilaku seseorang. Masingmasing suku telah memiliki tata krama pergaulan dan disiplinya sendiri-sendiri yang sudah mapan dan berbeda satu dengan lainnya. Pada masyarakat yang hidup dalam lingkungan strata elite, tata krama menjadi simbol untuk memperkuat identitas jati diri mereka dalam kelompok yang dominan.

Etika atau tatakrama sebagai pandangan manusia dalam berprilaku menurut ukuran dan nilai yang baik. Tata krama yang baik dan sesuai dengan etika pada umumnya dipahami pada tingkat masyarakat elite, oleh karena itu tata krama menjadi panutan bagi sekelompok masyarakat dalam bertindak dan berprilaku. Dalam kehidupan masyarakat Buton telah menanamkan tiga pilar norma yaitu norma hukum, norma sosial dan adat istiadat. Masing-masing norma tersebut memiliki peranan penting dalam kehidupan masyarakat,karena dapat menjadi pedoman bersikap dan berprilaku (Sahlan,2012:315). Pada masyarakat golongan bangsawan Buton tata krama sudah menjadi tuntunan identitas dan penguatan status sebagai masyarakat yang paham dengan tata krama dan etika dalam berprilaku. Berbeda halnya pada masyarakat yang berada dalam hirarki stratifikasi sosial yang terendah dalam kelompok masyarakat tradisional. Mereka dianggap tidak memiliki Tata krama dan budaya, sehingga segala perilaku dan tutur katanya tetap menjadi cemoohan bagi masyarakat dari kalangan atas atau elite tradisional yang terus menerus di reproduksi sebagai penguatan status dalam stratifikasi sosial.

Orang Katobengke misalnya merupakan salah satu subetnik Buton yang mengalami diskriminasi dan stigmatisasi pada era kesultanan Buton hingga orde baru. Temuan penelitian mengemukakan, bahwa sejak reformasi perlawanan orang Katobengke merefleksikan perjuangan penegasan identitas, mencari identitas baru. Secara spesifik orang Katabongke sedikit banyaknya diremehkan oleh masyarakat sekitar Keraton Wolio hanya karena mereka dari kelompok "papara" atau lapis terendah dari stratifikasi sosial. Kondisi ini direproduksi terus menerus, meskipun ada banyak masyarakat "papara" di seluruh komunitas Buton atau dapat dikatakan bahwa kebanyakan penduduk dalam masyarakat tersebut dapat dikelompokkan sebagai "papara", karena "papara" diartikan sebagai orang-orang yang tidak menggunakan Bahasa Wolio (Bahasa resmi Kesultanan). Ideologi harmoni elite kesultanan dinodai politik indirect rule Belanda dengan kekerasan membayar pajak terhadap rakyat, mewarisi orde baru memberi citra negatif terhadap orang Katobengke. Reformasi berjalan, ketidakpercayaan orang Katobengke terhadap ideologi elite tradisional, munculnya tiga kekuatan elite Katobengke: Katobengke Islam tradisional, Katobengke Islam murni, dan Katobengke elite modern untuk bersama menolak label budak terhadap diri mereka. Longgarnya kekerasan simbolik elite mengenai status kadie (wilayah desa) dan tabu adat. Sekarang ini orang Katobengke yang memahami Islam secara kaffa menyatakan ritual yang dilakukan orang Katobengke yang memahami Islam tradisional bertentangan dengan syariat Islam dan lunturnya karisma "Parabela". Tindakan menyembunyikan identitas sebagai strategi untuk membebaskan diri dari stigma elite tradisional. Predikat inana laode (ibu laode) dan amana laode (ayah laode) menjadi senjata elite Katobengke tidak mengindahkan adat elite tradisional yang melanggar norma adat dan agama. Dapat disimpulkan bahwa bentuk perlawanan orang Katobengke terjadi akibat perlakukan tidak adil elite tradisional sejak era kesultanan hingga orde baru. Ketidakberfungsian ideologi harmoni elite sebagai ekspresi penolakan predikat budak dan tabu adat. Perlawanan fisik sebagai representasi ketersinggungan historis yang terinternalisasi dalam diri mereka. 
Pelanggaran adat perkawinan, naik haji, gelar amana Laode, penguasaan tanah bekas kesultanan, mendapat reaksi pasif dari elite tradisional (Dirman, 2015:250).

Meskipun banyak yang mendiskreditkan posisi sosial orang Katobengke, mereka tidak takluk begitu saja oleh dunia sosial di luar diri mereka. Mereka membangun negosiasi makna dan strategi-strategi agar posisi mereka sejajar dengan pihak yang mendiskreditkan mereka. Mereka menolak untuk tunduk pada stigmatisasi budak tersebut. Mereka bernegosiasi dan melihat ulang sejarah serta penamaan kelompok mereka (Tahara, 2014: 11). Pada era globalisasi saat ini orang Katobengke melakukan berbagai upaya untuk menghilangkan citra buruk masa lalu yang terus menstereotipkan kaum mereka, dengan mengembangkan sumberdaya manusia di berbagai bidang, membangun perilaku dan tata krama dalam struktur budaya yang dinamis, sebagai penguatan jatidiri orang Katobengke.

Beberapa penelitian terdahulu yang ditulis berkaitan dengan tata krama suku bangsa dari golongan bangsawan seperti yang ditulis (Hafid dkk., 2000: 64) yaitu tata krama suku bangsa Mandar di Kabupaten Majene dikelompokan dalam dua bentuk tatakrama yaitu tata krama bertutur kata dan kedua tata krama bersikap atau tingkah laku. Demikian halnya dalam tulisan (Paeni dkk, 1990: 5) tentang tata kelakukan di lingkungan pergaulan keluarga dan Masyarakat Makassar yang mengungkapkan bahwa tata kelakuan suatu masyarakat yang dilandasi oleh gagasan nilai, dan keyakinan menjadi kerangka acuan aturan-aturan dimanifestasikan keluar oleh setiap individu berupa pergaulan. Menurut (Ariani dkk., 2002: 36) dalam tulisannya tentang Tata Krama Suku Bangsa Jawa di Kabupaten Sleman Propinsi Daerah Istimewa Yogyakarta, mengungkapkan bahwa tata krama, etika, atau sopan santun yang merupakan salah satu unsur budaya yang dimiliki oleh suku bangsa Jawa tidak terlepas dari sifat-sifat halus dan kasar. Sudah menjadi sifat umum bahwa segala perilaku salah tingkah manusia Jawa selalu didasarkan kepada estetika yang halus dan kasar.

Beberapa tulisan tentang tata krama yang ditulis oleh peneliti-peneliti budaya pada umum melihat tata krama suku bangsa dari kaum elite atau golongan bangsawan dari berbagai suku yang ada di Idonesia. Akan tetapi belum ada yang mencoba mengkaji bagaimana tata krama atau etika masyarakat golongan strata bawah. Apakah mereka tidak memiliki tata krama atau budaya sopan santun dalam lingkup kehidupan sosial mereka, karena mereka terlahir dari strata yang paling rendah.

Berdasarkan uraian yang telah dikemukakan tersebut maka saya tertarik untuk melakukan penelitian tentang bagaimana sebenarnya tata krama atau etika keseharian masyarakat Katobengke, sehingga para kaum elite tradisional di Buton begitu mendeskreditkan mereka sebagai kelompok masyarakat yang terendah, yang harus dijauhi dan sampai sekarang reproduksi stereotip terhadap kelompok masyarakat ini masih membayangi kehidupan sosial mereka. Walaupun adat sopan santun atau yang biasa disebut etiket telah menjadi aturan dalam hidup kita, telah menjadi persyaratan dalam hidup sehari-hari, malahan menjadi meningkat dan sangat berperan untuk memudahkan manusia diterima di masyarakatnya. Masyarakat Katobengke sebagai kelompok masyarakat yang termarginalkan dalam kehidupan sosial budaya kaum elite disekitarnya, apakah mereka memiliki tata krama dalam berprilaku. Untuk menjawab pertanyaan tersebut maka fokus masalah dalam tulisan ini adalah "Bagaimana Tata Krama Dalam Adat Istiadat Orang Katobengke", dengan rumusan masalah adalah: (a) Bagaimana bentuk-bentuk tata krama Orang Katobengke dalam kehidupan sehari-hari di lingkungan keluarga dan masyarakat, (b) Bagaimana tata krama Orang Katobengke dalam upacara adat. Adapun tujuan penelitian ini untuk mengetahui dan mendeskripsikan tata 
krama orang Katobengke, yang selama ini termarginalkan dalam lingkup masyarakat elite tradisional terutama bagi kaum kaomu (kelompok sultan) dan walaka (yang menyeleksi sultan) di zaman kesultanan Buton.

\section{B. METODE PENELITIAN}

Penelitian ini adalah penelitian yang bersifat deskriptif dengan memfokuskan pada bentuk-bentuk tata krama orang Katobengke baik dalam lingkungan keluarga maupun di masyarakat dan sejarah kehidupan sosial orang Katobengke. Ketiga faktor tersebut merupakan hal yang penting untuk diungkapkan secara deskriftif kualitatif. Mengingat bahwa orang Katobengke berada dalam kelompok masyarakat yang termarginalkan dari kelompok masyarakat elite tradisional di Buton. Pendekatan penelitian yang digunakan adalah pendekatan kualitatif. Pendekatan ini diharapkan dapat mengungkap permasalahan yang berhubungan dengan penelitian ini. Dalam pendekatan kualitatif, cara hidup dan cara pandang atau ungkapan-ungkapan emosi dari warga masyarakat yang diteliti mengenai suatu gejala yang ada dalam kehidupan mereka itu justru digunakan sebagai data (Moleong, 2001: 4).

Lokasi penelitian di tentukan secara purposive di Kelurahan Katobengke Kecamatan Betoambari Kota Bau-Bau. Pemilihan lokasi tersebut didasarkan atas pertimbangan bahwa di tempat ini bermukim masyarakat Katobengke, yang masih mempertahankan adat istiadat dan tata krama dalam lingkup keluarga dan masyarakat. Data yang dikumpulkan dalam penelitian berasal dari 2 sumber, yaitu data primer dan sekunder. Data primer, yaitu data yang diperoleh langsung melalui wawancara dengan informan yang terdiri atas: parabela, tokoh-tokoh adat, tokoh pemuda, imam kampung, dan warga Katobengke yang dipilih secara acak sesuai kebutuhan data penelitian. Teknik wawancara dengan menggunakan panduan wawancara (interview guide) dalam hal ini tata krama dan etika masyarakat Katobengke dalam lingkungan keluarga dan masyarakat. Data sekunder, yaitu data tertulis yang diperoleh dari sumber arsip-arsip lokal yang berguna bagi penelitian seperti, Badan Pusat Statistik, serta organisasi non pemerintahan (LSM), dan sumber kepustakaan, seperti jurnal, artikel, makalah, tesis, disertasi, dan internet. Data ini meliputi: keadaan geografis dan luas wilayah, topografi dan iklim, kondisi demografi, Kelurahan Katobengke Kota Bau Bau.

Teknik Analisis data dalam penelitian ini digunakan metode analisis deskriftif- kualitatif, yaitu analisis data dilakukan sejak awal penelitian dan selama proses penelitian dilaksanakan. Data diperoleh, kemudian dikumpulkan untuk diolah secara sistematis. Dimulai dari wawancara, observasi, mengedit, mengklasifikasi, mereduksi, selanjutnya aktivitas penyajian data serta menyimpulkan data. Teknis analisis data dalam penelitian ini menggunakan model analisis interaktif. Pada penelitian ini, verifikasi data dilakukan secara terus menerus sepanjang proses penelitian dilakukan. Sejak pertama terjun ke lapangan dan selama proses pengumpulan data, peneliti berusaha untuk menganalisis dan mencari makna dari data yang dikumpulkan. Pada akhirnya, data akan diinterpretasikan dalam kaitannya dengan materi penelitian. Hasil analisis data merupakan jawaban terhadap masalah yang dikemukakan dalam penelitian ini.

\section{HASIL DAN BAHASAN \\ 1. Profil Masyarakat Katobengke}

Orang Katobengke, adalah salah satu kelompok masyarakat asli pulau Buton di Sulawesi Tenggara. Orang Katobengke, hadir di daratan Sulawesi bersama-sama dengan orang Moronene dan orang Toaere, yang diperkirakan sekitar 2000 tahun Sebelum Masehi. Kehadiran orang-orang Katobengke ini menurut para ahli datang dari Gobi, Yunnan dan Indochina semenanjung 
Malaka bersama rombongan bangsa Protomalayan lainnya, seterusnya menyebar ke daerah selatan dan timur yang menjadi beberapa suku tua yang mendiami Sulawesi. Keranjang usungan (bhaki) yang dipakai orang Katobengke di pedalaman Buton memiliki kesamaan bentuk dengan keranjang usungan sukusuku di hindia belakang. Hal ini memperkuat dugaan bahwa orang Katobengke adalah migran dari daerah Hindia belakang yang meliputi kawasan China selatan dan Indochina.

Masyarakat Katobengke adalah bagian dari masyarakat Buton yang heterogen. Mereka memiliki beberapa kepercayaan yang sedikit berbeda dengan masyarakat Buton lainnya, namun secara umum mereka juga sebagai orang Buton asli. Orang Katobengke telah hidup bersama dengan suku-suku lain di Buton. Orang Katobengke kadang dianggap bukan sebagai etnis yang terdapat di Buton, walaupun etnis Katobengke memiliki populasi yang lumayan besar, dan memiliki sejarah panjang termasuk memiliki peran penting dalam menyangga perjalanan Kerajaan Buton.

Di masa silam posisi orang Katobengke merupakan kelompok papara yang menetap di wilayah kadie (wilayah desa) dalam kesultanan Buton, merupakan kelompok papara paling istimewa dibanding dengan papara lainnya karena posisi wilayah mereka yang berdekatan dan mendampingi ibukota kesultanan (wolio). Mereka adalah pekerja yang digaji oleh bangsawan kelompok kaomu ataupun walaka. Dalam tradisi kesultanan Buton, kelompok yang berhak mempekerjakan kelompok papara hanya bangsawan kelompok kaomu dan walaka (Tahara, 2014:119).

Menurut Rudyansah (2009: 29) menyatakan bahwa klasifikasi kelas penguasa dan kelas yang dikuasai dalam kesultanan Buton menjadikan struktur masyarakat Buton dalam tiga lapisan masyarakat yakni (1) kaomu (bangsawan), (2) walaka (menengah) dan (3) papara (rakyat desa) yang menempati 70 wilayah desa (kadie) dan dua kadie berada dalam benteng Kraton Buton yang ditempati golongan penguasa atau elite tradisional. Sedang Zuhdi (2010: 76) mengklasifikasikan bahwa kaomu dan walaka adalah peletak dasar kerajaan Buton, sedangkan lapisan papara adalah orang jauh yang tidak diketahui asal usulnya. Selanjutnya ia merinci lapisan keempat adalah batua (budak) yang berasal dari papara karena tidak membayar pajak. Sedang kantinale adalah budak yang dimerdekakan dan papara adalah budak yang dirampas dari tangan musuh.

Masyarakat di dalam wilayah Kesultanan Buton didefinisikan ke dalam orang wolio dan non-wolio. Dua kategori dan walaka, termasuk ke dalam kategori orang wolio. Sebaliknya dua kategori tingkat sosial yang terakhir, yakni papara dan batua, termasuk dalam kategori bukan orang Wolio (non-Wolio). Golongan kaomu merasa lebih tinggi tingkat sosialnya dengan golongan walaka, walaupun sebenarnya sama-sama sebagai orang Wolio.

Menurut konsepsi budaya masyarakat wolio, orang-orang dari kaomu dan walaka dibedakan dari orang-orang papara dan batua, karena kedua kelompok yang pertama berasal dari orang Wolio dan dapat diketahui asal-usulnya berasal dari keturunan kerajaan, sedangkan dua kelompok yang terakhir berasal dari daerah pedalaman dan bukan dari keturunan kerajaan. Orang dari golongan kaomu dan walaka, menganggap papara bukanlah dari keturunan kerajaan dan sehingga orang kaomu dan walaka merasa status mereka lebih tinggi dari orang golongan papara. Sedangkan batua, merupakan satu kategori tingkat sosial yang bersifat residual dari kelompok papara. Orang dari golongan batua sebetulnya berasal dari kelompok papara yang diturunkan derajatnya karena tidak bisa membayar hutang, atau melanggar adat, atau merupakan orangorang yang ditangkap dalam perang di wilayah musuh. Orang Katobengke yang dimasukkan ke dalam golongan Papara, 
tentunya sangat menolak ampon yaitu tingkatan sosial, yang diterapkan oleh Kesultanan Buton dan Kesultanan Wolio. Orang Katobengke, merasa nama "Katobengke" begitu kuat berasosiasi dengan istilah "Papara". Maka dari itu mereka berusaha mengganti identitas mereka dari orang Katobengke menjadi orang Lipu.

Dinamika keberadaan Orang Katobengke sebagai salah satu etnis tertua di Sulawesi Tenggara memiliki sejarah panjang serta budaya dan adat-istiadat sendiri, namun saat ini telah berkembang menjadi masyarakat yang maju. Banyak dari mereka yang telah merantau ke berbagai daerah di Indonesia dan berhasil menunjukkan eksistensi keberadaan mereka. Sebagian besar masyarakat Katobengke hidup pada bidang pertanian, seperti tanaman padi, jagung, ubi kayu, ubi jalar, sayuran dan buah-buahan. Tidak sedikit juga yang memilih profesi sebagai pegawai di pemerintahan maupun swasta.

\section{Tata Krama Dalam Lingkungan Keluarga dan Masyarakat \\ a. Tata Krama dalam pergaulan dan kehidupan sehari-hari}

Pada masyarakat Katobengke tata krama dalam pergaulan sehari-hari masih diatur dalam suatu norma dan acuan dari pemimpin adat yaitu parabela, sehingga tata krama dan adat istidat menjadi aturan dalam masyarakat Katobengke. Adapun bentuk-bentuk tata krama dalam dalam pergaulan dan kehidupan sehari-hari masyarakat Katobengke adalah sebagai berikut:

\section{a) Tata krama menyapa dan bersikap}

Dalam setiap budaya terdapat istilah-istilah kekerabatan yang dipakai menyapa terhadap kerabat lain dalam hubungan pembicaraan. Orang katobengke menyapa atau memanggil orang-orang yang ada dalam lingkungan keluarga misalnya ibu dengan sebutan ina, bapak = ama, paman = Fokoama 'o, Bibi = Fokoina'o, nenek = naina dan kakek = mama. Kalau menyapa kakak, dengan sebutan mbainoisa, kalau adik mbainoai, sepupu dari ayah dan ibu= sepisa, cucu= yoompu. Sebagai akibat perkawinan terjadilah keluarga inti (nuclear family), yang dalam bahasa Buton disebut kobhanua artinya satu keluarga yang terdiri atas ayah, ibu dan sejumlah anak (ana). Sapaan ini memberi kesan keakraban dalam keluarga, sehingga dianggap suatu kesopanan dalam hal menyapa atau memanggil. Sedang sapaan sebagai bentuk kesopanan di luar lingkup keluarga dengan tidak menyebut nama ibu tersebut tetapi menyapa ibu tetangga dengan menyebut nama anak tertua laki-lakinya misalnya Hasan, maka ibu itu dipanggil atau disapa dengan ina Hasan, ina Ady dan sebagainya. Apabila tidak memiliki anak laki-laki, maka boleh menyapanya dengan menyebut nama anak perempuan pertamanya, karena dianggap tidak sopan apabila menyapa dengan menyebut nama yang bersangkutan. Orang Katobengke memiliki pemimpin tradisional atau ketua lembaga adat yang sangat dihormati dan disegani yaitu parabela. Orang tidak boleh menyapa parabela dengan menyebut nama aslinya, akan tetapi harus memanggilnya dengan kata "ama", kemudian mengikuti nama anak laki-laki pertamanya misalnya anak laki-laki bernama Izy, maka ia disapa dengan “ ama izy".Atau boleh menyebut atau memanggilnya dengan sebutan parabela.

Tata krama dalam menyapa yang telah disepakati merupakan bentuk penghormatan kepada orang yang dituakan atau bentuk kesayangan kepada orang yang lebih muda. Orang Katobengke pada umumnya memanggil nama dengan memakai kata $L a$ di depan nama untuk laki-laki dan $W a$ untuk perempuan, misalnya La Sade, La Manila dan perempuan Wa Nyla dan sebagainya. Namun sekarang ini penambahan kata $L a$ dan wa sudah mulai berkurang digunakan masyarakat Katobengke dalam pemberian nama pada anak laki-laki dan perempuan mereka. Menurut Tahara (2014: 121) pada zaman Kesultanan Buton Orang 
Katobengke mendapat panggilan amana laode (ayah laode) untuk kaum laki-laki dan inana waode (ibu waode) untuk perempuan, karena pada masa itu orang Katobengke mendapat tugas sebagai perawat anak-anak dari kelompok kaum kaomu dan walaka. Namun panggilan itu bukan merendahkan orang Katobengke melainkan sebagai penghormatan kelompok kaomu dan walaka karena telah membantu mengasuh anak-anak mereka.

Dalam keluarga senantiasa diterapkan kepada anak-anaknya untuk menyapa dengan hormat kepada yang lebih tua, terutama kepada kedua orang tua, atau yang tuakan. Sapaan yang sopan, biasanya diajarkan kepada anak sejak kecil hingga remaja. Dalam keluarga inti biasaya nenek bersama ibu yang selalu menerapkan sapaan sopan tersebut kepada anak dan cucunya. Pada masyarakat Katobengke, biasanya satu rumah tangga hidup dalam satu keluarga besar, yang terdiri atas ayah, ibu, anakanak, nenek dan kakek, maka penerapan tata krama dalam menyapa senantiasa diajarkan, sebagai bagian dari pola pewarisan dalam bertutur kata dan bersikap. Setiap anggota keluarga berhak mengurus dan menjaga nama baik keluarga dalam berperilaku terutama untuk menyapa orang-orang yang berada dalam lingkungan keluarga dan masyarakat disekitarnya.

Bagi orang Katobengke tata krama dalam bersikap menunjukkan perilaku sopan santun yang dimiliki seseorang. Tata krama menghormat dengan sikap dapat diungkapkan berdasarkan situasi dan kondisi di mana seseorang berada. Bagi anak-anak apabila berkumpul dengan orang yang lebih tua, maka dibatasi oleh berbagai sikap misalnya, menyapa, duduk, dan makan bersama orang yang lebih tua. Ketika seorang anak yang mau melintas dihadapan orang tua, maka ia harus berjalan membungkuk sebagai bentuk penghormatan kepada orang yang lebih tua, sikap demikian disebut dengan istilah "tabea".
Menurut konsep ideal dalam tata krama menghormat bagi masyarakat Katobengke, tidak ada penghormatan khusus yang membedakan antara orang tua, kakek/nenek, paman/tante, dan orang yang lebih tua. Kesemuanya harus dihormati sesuai adat dan kebiasaan masyarakat setempat. Sikap anak ketika berbicara dengan orang tua atau yang dituakan pada saat berdiri, maka sikap anak harus sedekit menunduk dan kedua tangan diletakkan di depan dan rapat menjulur ke bawah, akan tetapi apabila yang dilawan bicara itu sedang duduk, maka terlebih dahulu duduk baru berbicara. Anak tidak boleh bermain-main ketika berbicara dengan orang yang lebih tua, harus fokus dan berkata dengan nada yang rendah, tidak boleh berbicara dengan nada menantang.

Dalam lingkungan keluarga parabela seorang anak harus selalu patuh dengan tata krama yang diatur oleh adat istiadat. Anak parabela ketika meminta sesuatu yang dinginkan tidak boleh meminta langsung kepada parabela, selaku ayah akan tetapi melalui ibu atau istri parabela. Walaupun parabela adalah sosok ayah, dalam lingkungan keluarganya, namun anak-anak dan istrinya tetap menganggap beliau sebagai pigur yang dihormati. Sikap patuh dan hormat anak dan istri kepada parabela menjadi contoh panutan bagi masyarakat Katobengke. Begitu pula dalam lingkungan lembaga adat, sikap dan perilaku parabela sebagai ketua adat dan sangat dihormati, sehingga ketika menyebut namanya dianggap tidak sopan dan melanggar tata krama. Parabela adalah panutan masyarakat Katobengke, segala tindakan dan sikapnya dipantau oleh masyarakatnya. Ketika parabela terjatuh atau terpeleset, dan dilihat oleh warganya maka pertanda akan terjadi malapetaka dan wabah penyakit di kampung tersebut. Apabila kejadian itu terjadi pada parabela, maka diadakan musyawarah adat untuk mengganti parabela, karena ditakutkan akan menimpa semua warga. Akan tetapi 
sewaktu parabela terjatuh atau terpeleset, tidak seorangpun yang melihatnya, maka parabela melakukan tolak bala dengan cara berdoa di dalam kamar, tempat benda pusaka berada. Perilaku ini untuk memohon kepada yang Kuasa dan penghuni benda pusaka agar warga masyarakat Katobengke terhindar dari malapetaka dan wabah penyakit. Ketentuan ini berlaku pula pada istri parabela, sehingga istri parabela harus selalu menjaga sikap dan tindakan di masyarakat.

Penuturan La Zade (29 tahun), sebagai generasi muda orang Katobengke berupaya tetap mempertahankan tata krama dalam menyapa dan berperilaku sebagai tradisi yang harus dipatuhi karena sesuai dengan aturan adat. Kami sebagai anak muda orang Katobengke selalu diajarkan agar menghindari perkelahian atau perseteruan dengan siapa saja, karena ini bertentangan dengan adat istiadat dari leluhur orang Katobengke. Sebagai anak seorang parabela La zade adalah panutan dimasyarakat, apabila terjadi perselisihan dikalangan anak muda di Katobengke, maka ia didaulat untuk mendamaikan, namun apabila tidak bisa didamaikan maka persoalan ini di bawa ke parabela. Keputusan parabela oleh masyarakat Katobengke adalah keputusan yang adil dan harus dipatuhi karena dianggap sakral apabila dilanggar akan mendapat sanksi adat. (wawancara 9 Mei 2017).

\section{b) Tata Krama Duduk}

Posisi duduk seseorang menjadi salah satu bentuk kesopanan yang perlu dilakukan, pada saat kita berada pada suatu kondisi tertentu. Posisi duduk ketika berhadapan dengan orang lebih tua berbeda ketika duduk bersama teman sebaya. Demikian pula ketika sesorang bertamu, maka posisi duduk menjadi cerminan perilaku seseorang. Pada masyarakat Katobengke tata krama duduk, menjadi suatu kepatutan. Seorang anak atau orang dewasa harus selalu memperlihatkan sikap yang sopan ketika duduk, baik ketika berada dalam lingkungan keluarga maupun dalam lingkungan masyarakat. Ketika anak duduk bersama dengan orang yang lebih tua, maka sikap yang dianggap sopan bagi lakilaki adalah duduk bersila dan perempuan duduk menyamping dengan melipat kaki kebelakang. Tangan pada posisi terlipat di depan dan badan sedikit membungkuk, posisi duduk ini dianggap sebagai suatu bentuk tata krama yang ideal.

Dalam adat istiadat orang Katobengke sikap duduk seorang parabela menjadi simbol tata krama dalam lingkungan adat. Parabela ketika duduk pada saat menerima tamu, maka posisi duduknya bersila dengan mengenggam tangan dan sedikit menunduk adalah posisi duduk yang sesuai dengan adat istiadat orang Katobengke. Demikian pula ketika seseorang menghadap ke parabela, maka sikap duduk yang dianggap sopan dan sesuai dengan tata krama yaitu, bagi lakilaki sikap duduk bersila dan melipat tangan dan bagi wanita posisi duduk rapat dengan kaki menyamping. Posisi duduk secara melingkar berhadapan dengan parabela, namun ketika akan menggeser ke depan atau ke belakang maka posisinya berjalan jongkok.

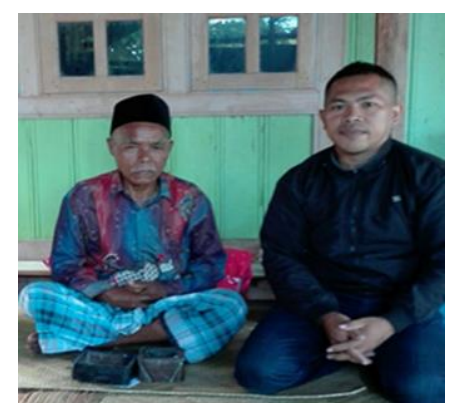

Gambar.1. Posisi duduk dihadapan parabela Sumber: Lazade, 2017

Dalam musyawarah adat tata krama duduk menjadi posisi yang penting dalam lembaga adat masyarakat Katobengke. Posisi duduk menunjukan jabatan yang diembannya pada saat itu. Untuk mengetahui apa jabatan para pemangku adat, maka dilihat dari dimana ia duduk. Pada acara adat posisi duduk parabela berdampingan dengan imam kampung, dan 
wati agak ke depan. Apabila dalam musyawarah adat itu hadir mantan parabela, mantan imam dan anak-anak mantan parabela dan imam, maka posisi duduknya adalah: parabela, kemudian disamping parabela adalah mantan parabela kemudian imam dan mantan imam, yang berada di sebelah kanan. Pada bagian kiri posisi duduk anak parabela berdampingan dengan anak mantan, dan anak imam dan anak mantan imam. Letak posisi duduk seperti ini sudah menjadi aturan adat sebagai suatu tata krama dalam kelembagaan masyarakat Katobengke.

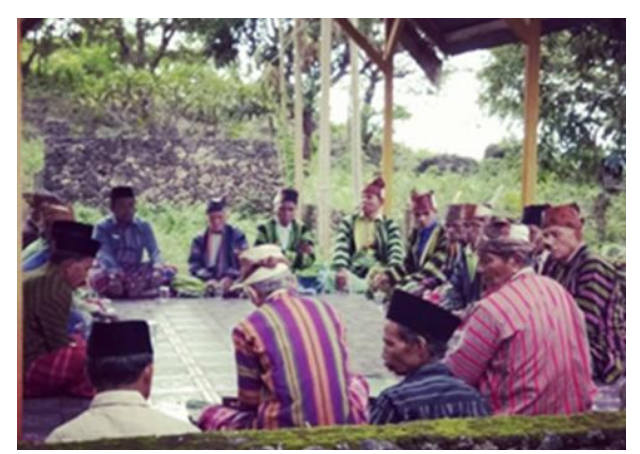

Gambar.2 Posisi duduk dalam musyawarah adat

Sumber: La zade,2017

\section{c) Tata Krama Dalam Berpakaian}

Berbagai ragam budaya daerah di Indonesia terlihat dari ragam dan corak pakaian yang dikenakan, mencerminkan status sosial dan jati diri orang yang memakainya. Menurut Melamba (2012: 194) sebagaimana ia mengutip Henk, menyatakan bahwa pakaian berperan besar dalam menentukan identitas komunitas dan citra seseorang. Lebih dari itu, pakaian adalah cerminan dari identitas, status, hierarki, gender, memiliki nilai simbolik, dan merupakan ekspresi cara hidup tertentu. Pakaian juga mencerminkan sejarah, hubungan kekuasaan, serta perbedaan dalam pandangan sosial, politik, dan agama. Dengan kata lain, pakaian adalah kulit sosial dan kebudayaan kita. Pada sebagian masyarakat tata krama dalam berpakaian merupakan pranatapranata sosial yang dipatuhi sebagai salah satu etika dalam pergaulan. Orang Katobengke adalah masyarakat yang hidup dalam lingkungan adat, maka adat berpakaian menjadi ciri khas pembeda dengan orang komunitas adat lainnya. Sebagai ketua adat parabela menjadi contoh yang baik dalam berpakaian, parabela dalam kesehariannya berpakaian sesuai dengan tata krama setempat yaitu memakai sarung dan kemeja lengan panjang serta memakai kopiah. Parabela tidak boleh memakai kemeja lengan pendek atau tidak memakai kopiah ketika menerima tamu, karena melanggar adat. Sedang istri parabela sehari-hari memakai pakaian biasa yaitu blus dan sarung. Menurut tata krama istri parabela tidak boleh memakai rok sebagai pengganti sarung, untuk membedakannya dengan masyarakat umum.

Dalam keseharian orang katobengke mengenakan pakaian seperti masyarakat lainnya, yaitu perempuan dewasa mengenakan blus dan sarung atau rok, sedang anak perempuan remaja berpakaian sesuai dengan model pakaian sekarang. Untuk laki-laki mengenakan pakaian kaos, celana panjang dan kemeja, baik yang dewasa maupun remaja. Tidak ada perbedaan dalam berpakaian antara orang Katobengke dan masyarakat lainnya yang ada di Buton, mereka juga mengikuti perkembangan mode terbaru, sehingga stigma orang terhadap masa lalu orang Katobengke menjadi sirna dengan pesatnya perkembangan informasi dan teknologi yang merambah wilayah pemukiman orang Katobengke.

Sebagai masyarakat adat Orang Katobengke mempunyai pakaian adat yang dikenakan pada acara pesta adat (haruo). Baju adat orang Katobengke disebut Pakaian Balahadada merupakan pakaian kebesaran yang dikenakan oleh kaum lakilaki Buton baik bagi seorang bangsawan maupun bukan bangsawan. Pakaian dengan warna dasar hitam ini dijadikan sebagai perlambang keterbukaan pejabat atau sultan terhadap segala sesuatu yang berkaitan dengan urusan masyarakat demi pencapaian kesejahteraan dan kebenaran hukum yang diputuskan dengan jalan musyawarah untuk mufakat. Kelengkapan 
pakaian Balahadada terdiri atas destar (penutup kepala), baju, celana, sarung, ikat pinggang, keris, dan bio ogena atau sarung besar yang dihiasi dengan pasamani diseluruh pinggirannya. Yaitu sejenis jubah (leja) berbentuk baju panjang yang bahannya terbuat dari tenunan khas Buton. Ragam corak tenunan Buton yaitu garisgaris warna-warni dasar kainnya biasanya hitam, atau biru. Baju inilah yang dikenakan parabela, imam dan wati. Apabila parabela tidak memakai baju adat boleh menggantinya dengan memakai jas dan sarung untuk menghadiri acara adat, isalnya acara perkawinan.

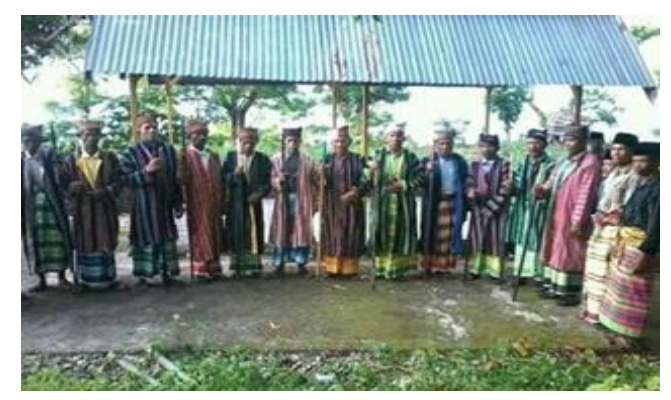

Gambar.3. Pakaian adat laki-laki orang Katobengke

Sumber: La Zade,2017.

Kambowa merupakaan pakaian adat wanita Buton berbentuk ponco dan tidak memiliki kerah yang digunakan oleh para ibu, gadis maupun anak-anak dalam berbagai upacara adat maupun sebagai pakaian hari-hari pada masa lampau. Bagi kaum bangsawan penggunaan baju kambowa ini biasa dipadukan dengan kain sarung yang terdiri dari tiga lapis, sedang untuk rakyat biasa hanya menggunakan satu lapis sarung. Bagi istri parabela, imam dan wati, mempunyai tata krama dalam berpakaian pada acara-acara adat, yaitu mengenakan blus lengan panjang mirip kebaya kemudian memakai sarung tenun Buton 4 (empat) lapis yang berbeda warna. Menurut istri imam adat Katobengke, bahwa pemakaian sarung sebanyak 4 (empat) lapis, sekarang ini tidak lagi dilakukan karena membuat gerah bagi yang memakainya, apalagi untuk menghadiri acara adat dengan waktu cukup lama. Untuk kenyamanan dalam pemakaian kain sarung adat ini, kaum wanita di Katobengke memodifikasi hanya memakai kain sarung satu lapis. Namun pada tepi kain sarung diberi jahitan tiga lapis kain sarung yang berbeda warna sehingga kelihatannya memakai empat lapis kain sarung, yaitu sarung pertama dan sarung kedua dimodifikasi dengan tiga warna kain sarung, sehingga terlihat 4 (empat lapis) kain sarung (wawancara 12 Mei 2017).

Pakaian yang dikenakan oleh masyarakat Katobengke dapat dibedakan atas pakaian sehari-hari, baik untuk di dalam maupun di luar rumah. Pakaian untuk bepergian dan pakaian pesta. Dalam berpakaian harus memenuhi unsur kesopanan sesuai dengan tata krama yang berlaku di lingkungan masyarakat Katobengke. Tata krama penggunaan pakaian adat pada masyarakat Katobengke hanya untuk perangkat adat, baik laki-laki maupun perempuan. Sedang masyarakat biasa hanya menggunakan pakaian yang umum digunakan masyarakat yaitu blus dan sarung. Kaum wanita Katobengke yang bukan istri perangkat adat tidak boleh memakai pakaian adat pada upacara adat maupun pada pesta-pesta lainnya.

Sekarang ini kaum wanita Katobengke dalam keseharian sudah banyak memakai pakaian muslim, mereka mengenakan hijab baik wanita dewasa maupun remaja. Modernisasi dalam berpakaian terus menerus merambah wilayah masyarakat Katobengke. Pada berbagai pesta adat pakaian yang dikenakan sudah dimodifikasi, baik bahan yang digunakan maupun model sudah mengalami perubahan, namun bentuk aslinya masih tetap terlihat. Walapun demikian tata krama dalam berpakaian orang Katobengke masih disesuaikan dengan kondisi dan situasi penggunaannya.

\section{d) Tata Krama Makan dan Minum}

Dalam berbagai kondisi tata krama makan dan minum menjadi salah satu bentuk kesopanan yang menjadi etika dalam lingkungan keluarga dan masyarakat. Tata krama makan dan minum 
dapat diungkapkan berdasarkan waktu makan, tempat makan, pakaian saat makan, tata cara makan dan sikap pada saat makan dan minum.

Dalam masyarakat Katobengke waktu makan disesuaikan dengan kebiasaan yang berlaku di masyarakat. Pada waktu pagi ada sebagian masyarakat yang makan dengan nasi dan lauknya, ada pula yang makan kue-kue dan minum teh atau kopi. Tergantung dengan kebiasaan, sebagaimana yang dikatakan Wa Nyba (45 tahun) kebiasaan waktu makan di keluarganya disesuaikan selera anak dan suaminya. Biasanya sebelum berangkat kesekolah ia menyediakan sarapan pagi untuk anak-anaknya berupa nasi dan lauknya. Sedang suaminya hanya meminum kopi dan makan kue sebagai sarapan paginya. Pada siang hari sekitar jam 12.00 WITA pada umumnya orang Katobengke makan jagung, ubi (singkong) dan nasi. Tapi dominan mereka makan ubi yang diolah menjadi makanan tradisional pengganti nasi yang disebut kasuami, sejenis makanan yang terbuat dari parutan singkong yang dikukus dan dibentuk menyerupai kerucut. Waktu makan malam biasanya sekitar jam 19.00 wita atau setelah sholat isha. (wawancara $18 \mathrm{Mei}$ 2017).

Sikap pada waktu makan dan minum, berdasarkan tata krama yang santun diajarkan sedari kecil oleh orangtuanya. Tata krama makan pada masyarakat Katobengke, ketika seorang anak apabila makan bersama dengan orang tua atau yang dituakan, maka anak harus mendahulukan orang tua untuk mengambil nasi dan lauk pauknya. Selama anak makan, ia tidak boleh banyak bergerak, apalagi berdiri untuk mengambil, tambahan makanan perilaku tersebut dianggap tidak sopan. Tidak berbicara saat makan, apalagi kalau mulut penuh makanan, dianggap melanggar etika. Bagi masyarakat Katobengke tata krama ini telah diajarkan sejak kecil sebagai bentuk pengajaran dalam berperilaku.

Tata cara makan pada umumnya masyarakat di Katobengke ketika makan duduk di atas tikar dengan bentuk melingkar. Anak laki-laki duduk bersila, tidak boleh jongkok dan anak wanita duduk merapat dengan kedua kaki menyamping, makan dengan menggunakan tangan. Sekarang ini masyarakat Katobengke sudah ada pula yang menggunakan meja makan, sehingga mereka duduk dikursi ketika makan. Tata krama makan di meja tidak boleh menaikkan salah satu kakinya di atas kursi dianggap tidak sopan. Apabila makan bersama tamu biasanya yang didahulukan untuk mengambil nasi dan lauk pauk adalah tamu, baru pemilik rumah. Untuk menjaga kesopanan dalam makan sebaiknya ketika mengunyah tidak mengeluarkan suara atau mengambil makanan dengan menggunakan tangan. Tata krama makan dalam keluarga didahulukan bapak untuk makan terlebih dahulu, baru anak-anaknya.

Pakaian waktu makan disesuaikan dengan kondisi ketika mereka makan, ketika makan di dalam lingkungan keluarga, maka pakaian yang dikenakan adalah pakaian yang dikenakan sebagai pakaian harian yang penting sopan. Dianggap tidak mengerti tata krama apabila ada dalam anggota keluarga, ada anggota keluarga yang makan tidak memakai baju, hanya memakai celana atau sarung saja. Sedang tata cara makan pada acara adat, maka pakaian yang dikenakan adalah pakaian adat atau pakaian pesta sesuai suasana dan kondisinya. Tata krama makan dan minum bukan hanya berlaku pada golongan bangsawan atau kaomu, akan tetapi bagi golongan masyarakat biasa tata krama ini berlaku. Pada masyarakat Katobengke ada image yang kurang baik, ketika seorang suami tampak makan di luar, misalnya makan di warung, maka anggapan orang yang melihatnya bahwa rumah tangga mereka sedang bermasalah. Sehingga dalam lingkup Orang Katobengke para suami pantang makan di luar apabila tidak bersama istrinya.

Adapun tata krama makan dalam keluarga parabela, berbeda dengan tata 
cara makan orang kebanyakan. Tata krama maka parabela diatur oleh adat yang berlaku. Parabela makan di atas talang (sejenis baki) yang berkaki yang terbuat dari kuningan dan penutupnya terbuat dari anyaman rotan. Nasi dan lauk di taruh dalam piring atau mangkuk kemudian diletakkan di atas talang. Cara makan parabela adalah duduk bersila di depan talang, makan dengan menggunakan tangan. Apabila makan bersama dengan anak dan istrinya, maka aturan makan harus parabela terlebih dahulu makan, baru diikuti anak dan istrinya. Begitu pula ketika parabela menghadiri pesta adat, maka cara makannya berbeda dengan tamu yang lain. Makanan disajikan harus di atas talang, dianggap melanggar aturan adat apabila parabela disajikan makanan dalam bentuk prasmanan. Karena parabela selaku pemimpin adat memiliki ampong, sehingga segala aktivitas kehidupannya di atur oleh tata krama dalam adat istiadat Orang Katobengke.

\section{Tata Krama dalam Upacara Adat}

Dalam berbagai upacara adat dan ritual Orang Katobengke sarat dengan aturan-aturan adat dan tata krama yang dipatuhi oleh masyarakat Katobengke. Ritual itu selain memiliki fungsi spiritual, juga memiliki makna sosial yaitu mempertahankan jaringan sosial yang ada di masyarakat. Dalam upacara adat ada aturan-aturan dan tata krama yang dipatuhi, sebagai suatu etika dalam bermasyarakat. Ada beberapa upacara adat, yang menjadi bagian kehidupan masyarakat Katobengke antara lain:

\section{a. Tata Krama dalam Perkawinan Adat}

Dahulu ada tata krama perkawinan adat dalam masyarakat Buton hanya terjadi pada status sosial yang setara misalnya kaomu dengan kaomu, walaka dengan walaka atau papara dengan papara, tujuannya untuk mempertahankan kemurnian status (Halking, 2014:179). Sistem perkawinan dalam masyarakat Buton pada umumnya termasuk orang Katobengke, menginginkan perkawinan dengan kerabat atau masih memiliki hubungan keluarga. Namun demikian perkawinan antara saudara sepupu sekali tidak diinginkan, tetapi diidealkan dengan kerabatnya atau hubungan keluarga yang sudah menjauh, misalnya sepupu empat kali (poabaaka) .Tata krama pelaksanaan suatu pesta perkawinan yang selalu dilakukan oleh masyarakat Katobengke, senantiasa dilakukan berdasarkan adat istiadat yang belaku. Ketika akan melaksanakan perkawinan, ada tahapan yang harus dilakukan oleh orang yang akan menyelenggarakan pesta perkawinan, yaitu terlebih dahulu meminta restu kepada parabela, untuk menentukan hari pelaksanaan pesta perkawinan. Pada masyarakat Katobengke ada atuaran yang selalu dipatuhi, yaitu tidak boleh dalam satu hari ada dua pihak yang melaksanakan pesta, baik itu pesta perkawinan, maupun pesta lainnya, karena hal tersebut melanggar aturan adat. Untuk menghindari kejadian ini, maka parabela yang harus menentukan waktunya, agar tidak bersamaan hari pelaksanaanya. Apabila terjadi dua pihak melaksanakan pesta pada hari yang sama, berarti ada pihak lain yang tidak memohon restu kepada parabela, dan parabela tidak berkewajiban menghadiri pesta tersebut.

Tata krama penyampaian pelaksanaan hari pesta kepada parabela, dilakukan oleh kedua orang tua calon mempelai perempuan maupun laki-laki, dengan cara mendatangi rumah parabela untuk meminta ditentukan hari dan tanggal pelaksanaanya yang disebut diala oleo. Parabela menentukan waktu pesta dengan menghitung menggunakan jari tangan, sesuai dengan pengetahuan tradisional disebut Kalentue malape yaitu penentuan hari baik. Bulan sya'ban berdasarkan kalender Islam yang dianggap baik untuk melaksanakan pesta adat baik pesta perkawinan maupun pesta adat lainnya.

$$
\text { Orang katobengke dalam }
$$

melaksanakan pesta tidak memberi undangan secara tertulis kepada masyarakat, akan tetapi mereka mengundang secara lisan dengan 
menyuruh tiga orang perempuan mendatangi rumah masyarakat untuk menyampaikan hari dan tanggal pelaksanaan pesta. Sedang pemanggilan hari pelaksanaan pesta bagi perangkat adat dan tokoh masyarakat disebut kakemba yaitu pemanggilan kedua setelah permohonan izin dari parabela. Dalam masyarakat Katobengke jarang terjadi ada dua pesta adat yang dilaksanakan pada hari yang sama, karena apabila hal tersebut terjadi, maka parabela tidak mendatangi salah satu pesta yang tidak meminta izin terlebih dahulu, dan ini pertanda buruk bagi yang melaksanakan pesta.

Begitu pula tata krama dalam mengahadiri pesta adat, parabela tidak boleh hadir di tempat pesta sebelum semua undangan telah hadir. Agar tidak terjadi kesalahan dalam menyambut kedatangan parabela, maka pemilik pesta perkawinan telah memastikan semua undangan telah hadir, baru mengutus orang untuk menjemput parabela. Ketika parabela datang semua orang dalam keadaan tenang dan parabela fokus, tidak boleh menoleh atau menyapa orang-orang yang hadir dipesta tersebut. Parabela sudah tahu posisi tempat duduknya tidak boleh salah karena ini melanggar tata krama dalam adat. Masyarakat Katobengke sangat patuh dan hormat pada perintah parabela karena diyakini bahwa perintah parabela adalah perintah leluhur mereka, kalau tidak diikuti akan mendapat "bala" atau bencana (Husain,dkk., 2012: 137).

Menu makanan yang disediakan untuk perangkat adat sedikit berbeda dengan tamu undangan lainnya, hal ini dilakukan sebagai penghormatan kepada perangkat adat. Undangan yang hadir tidak boleh makan terlebih dahulu sebelum pembacaan doa oleh parabela. Tamu baru bisa menyantap hidangan ketika parabela memulai menyantap makanan yang dihidangkan. Tata krama atau aturan adat ini sangat dipatuhi oleh penyelenggaraan pesta, agar pesta berlangsung secara hikmat. Tata krama makan seperti ini bukan saja pada acara pesta perkawinan, akan tetapi pada pelaksanaan ritual adat, yang dihadiri oleh perangkat adat.

Pelaksanaan upacara perkawinan di adat Katobengke sampai saat ini masih diarak dengan berjalan kaki. Ketika mempelai laki-laki akan melakukan akad nikah, maka rombongan mempelai lakilaki berjalan kaki menuju ke rumah mempelai perempuan. Begitu pula ketika mempelai wanita menuju ke rumah mempelai laki-laki maka dilakukan arakarakan. Tata krama dalam iring-iringan, posisi berjalan di depan adalah parabela dan perangkat adat, kemudian disusul istri parabela dan istri perangkat adat lainnya.

\section{b. Tata Krama pada Ritual Adat}

Ada beberapa upacara adat yang selalu dilaksanakan oleh masyarakat Katobengke yaitu upacara Tuturangi Lipu Morikana, dan Upacara adat Posuo. Upacara Tuturangi Lipu Morikana atau biasa juga disebut upacara pesta panen dirangkaikan upacara ziarah ke kuburan leluhur mereka di Lipu Morikana (kampung pertama orang Katobengke), yaitu ke makam parabela Mancuana yang diyakini sebagai nenek moyang orang Katobengke. Parabela selaku pemimpin upacara pada ritual adat ini, sedang pada acara keagamaan dipimpin oleh imam adat. Ketika ada upacara adat yang bertugas menyampaikan waktu pelaksanaan upacara tersebut, adalah wati yaitu pembantu parabela. Ada 2 (dua) orang wati yang bertugas membantu parabela untuk urusan luar dan pelaksana harian.

Tata krama dalam upacara adat tuturangi lipu dilakukan secara hikmat dan pembacaan doa dipimpin oleh parabela. Semua perangkat adat parabela, wati, imam dan khatib, hadir lengkap dengan pakaian kebesarannya yaitu jubah (leja). Upacara adat ini dilakukan dua kali yaitu pada awal penanaman (jagung dan ubi kayu) yang disebut Bongkana tao dan pada saat panen yang disebut fusianaliu. Parabela menentukan waktu pertama menanam, dan memulai penanaman, baru diikuti oleh petani lainnya. Aturan adat tidak boleh ada pesta perkawinan ketika 
berlangsung upacara bongkana tao. Tradisi Bongkana tao yang dilakukan masyarakat Katobengke, hingga saat ini masih terpelihara dan dilaksanakan secara turun temurun sebagai wujud rasa syukur rezeki yang diberikan Tuhan berupa hasil kebun atau pertanian (Ninik, 2016: 173). Dari penuturan Lazia (70 tahun), bahwa tata krama dalam upacara adat ini sudah mengalami perubahan baik dalam pelaksanaannya maupun substansinya. Dahulu banyak masyarakat yang bertani jagung dan ubi di kampung Lipu Morikana sebagai mata pencaharian pokok mereka, akan tetapi sekarang ini sudah tidak lagi, karena banyak masyarakat yang beralih profesi, disebabkan tanaman mereka sering dimakan babi, jadi mereka meninggalkan pekerjaan tersebut. Sehingga pelaksanaan ritual sekarang ini hanya sebatas ceremoni saja, yang menonjol adalah ritual ziarah kubur ke parabela Mancuana. (wawancara, 9 Mei 2017)

Sedang ritual adat lainnya yang selalu dilaksanakan oleh orang Katobengke adalah upacara posuo. Ritual ini bermakna pingitan bagi seorang gadis sebagai pertanda bahwa gadis tersebut telah memasuki fase orang dewasa. Ritual ini adalah proses yang harus dilalui oleh seorang gadis yang telah memasuki usia dewasa dan siap untuk dipersunting oleh laki-laki. Ritual wajib dilaksanakan oleh orang tua yang memiliki anak gadis untuk melakukan ritual posuo. Orang tua akan merasa malu dan tidak tahu adat apabila anak gadis mereka yang sudah remaja tidak di posuo. Ada aturan adat dalam ritual posuo yaitu anak gadis tersebut dipingit selama delapan hari dan delapan malam. Dalam masa pingitan tersebut dilakukan serangkaian acara adat yang cukup sakral. Pesta adat ini dilaksanakan secara besar-besaran dan mengeluarkan biaya yang cukup besar, karena dimeriahkan oleh pesta gendang dan tarian semalam suntuk. Dari sudut pandang sosiologis, posuo memiliki fungsi penguatan terhadap ikatan-ikatan sosial kemasyarakatan, dan merupakan bagian integral dari adat kebiasaan masyarakat Buton (Alifuddin, 2015: 2)

Setiap malam terdengar bunyi gendang dan gong yang dipukul dengan irama lembut, pemukulan gong dan gendang baru berakhir pada pagi harinya, demikian terus menerus sampai delapan hari. Dalam ritual posou ada dilakukan tari mangaru yaitu tari perang, yang dilakukan oleh kaum laki-laki dengan memakai pakaian kampurusi (destar) juba atau leja dan memakai keris. Tari mangaru ini biasanya di tarikan untuk penjemputan tamu, yang menceritrakan peristiwa masa lampau. Dahulu mangaru digunakan untuk melindungi parabela, dari gangguan kejahatan atau semacam pengamanan. Namun sekarang mangaru merupakan tata krama penghormatan kepada para undangan yang menghadiri acara pesta adat, atau pesta perkawinan. Pada saat penjemputan tamu di lakukan bore yaitu pantun berupa kata-kata yang bermakna kebaikan, isi pantun disesuaikan dengan acara pesta yang sedang berlangsung.

Dalam upacara posuo dipentaskan pula tari Linda dan tari Katiba, sebagai tari pergaulan. Tari Linda untuk perempuan dan tari katiba untuk laki-laki. Pada tari katiba dimainkan beberapa orang laki-laki menari menggunakan selendang, biasanya dimulai terlebih dahulu oleh orang tua, kalau pada acara tersebut hadir parabela, maka sebagai tata krama dipersilahkan terlebih dahulu kepada parabela untuk memulai menari baru kepada mantan parabela, selanjutnya kepada pemuda yang hadir. Sedang tari Linda dimulai ditarikan oleh istri parabela, kemudian istri mantan parabela dan selanjutnya kepada remaja putri yang hadir. Tari Linda dan Tari Katiba merupakan tari muda mudi dan oleh masyarakat Katobengke dijadikan sebagai ajang pencarian jodoh. Gerakan tari linda yang ditarikan oleh peserta dalam upacara adat ini terdapat beberapa ketentuan normatif dalam etika adat, sopan santun atau tata krama pergaulan serta tata krama dalam bertutur (Ardin,dkk., 2017: 60) 


\section{PENUTUP}

Anggapan tentang orang Katobengke yang tidak memiliki adat sopan santun oleh kelompok masyarakat elite tradisional di era kesultanan Buton ternyata tidak demikian. Sejak dahulu orang Katobengke sebagai kelompok masyarakat adat, memiliki tata krama dan sopan santun yang bersumber dari aturan adat, dan dipatuhi dan dijunjung tinggi sebagai identitas orang Katobengke. Perilaku sopan santun dalam lingkungan keluarga yang diimplimentasikan dalam kehidupan sehari-hari, memberi pemahaman kepada masyarakat di luar Katobengke, bahwa sahnya mereka memiliki adat istiadat yang tinggi sebagai penjelmaan dari tata krama dalam kehidupan bermasyarakat.

Parabela sebagai sosok pemimpin adat, menjadi simbol semua perilaku yang melekat pada dirinya. Konsekuensi yang diterima parabela sebagai pemimpin dalam masyarakat Katobengke, harus mampu sebagai panutan dari segala tindakan yang dilakukan. Peran parabela dalam berbagai aktivitas masyarakat Katobengke, dilakukan sesuai aturan adat dan tata krama yang berlaku. Dalam lingkungan keluarga orang Katobengke telah menerapkan tata krama dalam bersikap dan menyapa, tata krama dalam berpakaian tata, krama makan dan minum dan beberapa perilaku yang dianggap sopan.

Tata krama dalam hidup bermasyarakat diatur pula dalam berbagai upacara adat dan berkesenian. Pelaksanaan upacara adat adalah salah satu media dalam berinteraksi yang diatur dalam tata krama dan adat istiadat orang Katobengke. Sebagai bagian dari masyarakat Buton, orang Katobengke senantiasa membuka diri dalam upaya meningkatkan sumberdaya manusia, baik dari peningkatan ilmu pengetahuan maupun peningkatan perilaku melalui tata krama dan sopan santun dalam berintraksi dimasyarakat. Mereka mencoba melawan stereotip dari kaum elite tradisional yang selama ini menjadi bagian dari perjalanan kehidupan orang Katobengke. Perbedaan golongan dalam kelompok masyarakat yang melingkupinya, bukan penghalang untuk mereka mengukuhkan identitas dan jati diri sebagai kelompok masyarakat yang memiliki adat istiadat dan budaya yang tinggi.

Sampai sekarang orang Katobengke masih tetap konsisten mempertahankan adat istiadat dan budaya ditengah kehidupan modernisasi yang berkembang pesat di Kota Bau Bau. Oleh karena itu seyogyanya pemerintah Kota Bau Bau dan Dinas Kebudayaan senantisa memberi dukungan kepada kelompok masyarakat Katobengke dalam upaya pengembangan dan pelestarian kebudayaan daerah, sebagai bagian dari kebudayaan Nasional. Bagi Balai Pelestarian Nilai Budaya Sulawesi Selatan, perlu melakukan kajian yang berkelanjutan pada masyarakat Katobengke dari berbagai aspek budaya, guna penyebaran informasi dalam rangka pemanfaatan, pengembangan dan pelestarian budaya daerah.

\section{DAFTAR SUMBER}

\section{Jurnal, Makalah, Laporan Penelitian, Skripsi dan Tesis}

Alifuddin,Muhammad. "Siginfikansi Upacara Siklus Posuo Dalam Membangun Semesta Kepribadian Remaja Wanita Pada Masyarakat Buton" dalam Al Izzah Vol.10 No.1. Juli 2015.Hlm.1-17.

Ardin,dkk. "Makna Simbolik Pertunjukan Linda Dalam Upacara Ritual Karia di Kabupaten Muna Barat Sulawesi Tenggara" dalam Catharsis.Vol.6 N0.1 Agustus 2017.Hlm.57-64.

Dirman Laode, 2015.

Perlawanan orang Katobengke terhadap Hegomoni elite Tradisional Kota Bau-Bau Sulawesi Tenggara. Disertasi. Program Doktor.Program studi Kajian Budaya. Denpasar: Program Pascasarjana Universitas Udayana.

Halking, 2014. Tradisi Perkawinana Adat Buton Provinsi Sulawesi Tenggara: Kajian Tentang Hubungan Timbal Balik antara Agama Islam dan Tradisi Lokal. 
Disertasi. Makassar: Program Pasca Sarjana Universitas Islam Negeri Alauddin.

Husain, M.Najib,dkk. Penerapan. "Komunikasi Kelompok Dalam Kepeminpinan Parabela di Masyarakat Kabupaten Buton". Dalam Jurnal Ilmu Komunikasi Vol.10 No.2. Agustus 2012.Hlm.134-145.

Ninik Hindaryatiningsi. "Model Proses Pewarisan Nilai-Nilai Budaya Lokal Dalam Tradisi Masyarakat Buton. Jurnal Sosiohumaniora, Vol.18 No.2 Juli 2016. HIm 167-184.

Sahlan,2012. Kearifan Lokal Pada Kabanti Masyarakat Buton dan Relevansinya dengan Pendidikan Karakter. Jurnal el Haraka Vol.14 No.2 Tahun 2012

\section{Buku}

Ariani, Christriyati, dkk. 2002.

Tata Krama Suku Bangsa Jawa di Kabupaten Sleman Propinsi Daerah Istimewa Yogyakarta. Badan Pengembangan Kebudayaan dan Pariwisata Balai Kajian Sejarah dan Nilai Tradisional Yogyakarta. Proyek Pemanfaatan Kebudayaan Daerah Istimewa Yogyakarta.

Hafid, Yunus. 2000.

Tata Krama Suku Bangsa Mandar di Kabupaten Majene. Departemen Pendidikan Nasional Proyek Pengkajian dan Pembinaan Nilai-Nilai Budaya Sulawesi Selatan.

Moleong,L.J.2001.

Metodologi Penelitian Kualitatif Bandung: PT Remaja Rosdakarya.

Paeni Mukhlis, dkk.1990.

Tata Kelakukan di Lingkungan Pergaulan Keluarga dan Masyarakat Makassar. Departen Pendidikan dan Kebudayaan Direktorat Jenderal Kebudayaan Direktorat Sejarah dan Nilai Tradisional. Proyek Inventarisasi dan Pembinaan Nilai-Nilai Budaya.

Rudyansah,Tony.2009.

Kekuasaan, Sejarah, dan Tindakan: Sebuah Kajian Tentang Lanskap Budaya. Jakarta: Rajawali Pers.
Tahara Tasrifin, 2014.

Melawan Stereotip (Etnografi, Reproduksi Identitas, dan Dinamika Masyarakat Katobengke Buton yang Terabaikan). Jakarta: KPG (Kepustakaan Populer Gramedia).

Zuhdi, Susanto, 2010. Labu Rope Labu Wana: Sejarah Buton yang Terabaikan. Jakarta: Rajawali Pers.

\section{Website}

"7 Ragam Pakaian Adat Buton",diakses dari https://fitinline.com/article/read/7ragam-pakaian-adat-buton/, tanggal 9 September 2017

\section{Sumber Lisan/Informan}

Lazia (70 tahun), Imam Adat Katobengke, Kelurahan Lipu, wawancara, Mei 2017.

Lazade (29 tahun), Anak Parabela,

Kelurahan Katobengke, wawancara, Mei 2017.

WaNyba (45 tahun), ibu rumah tangga,

Kelurahan Katobengke, wawancara, Mei 2017 